\title{
Effects of High Pressure Treatment on Volatile Profile During Ripening of Ewe Milk Cheese
}

\author{
B. Juan, ${ }^{\star}$ L. J. R. Barron, $†$ V. Ferragut, ${ }^{\star}$ and A. J. Trujillo*1 \\ ${ }^{*}$ Centre Especial de Recerca Planta de Tecnologia dels Aliments (CERPTA), CeRTA, XiT, Departament de Ciència Animal i dels Aliments, \\ Facultat de Veterinària, Universitat Autònoma de Barcelona, 08193 Bellaterra, Spain \\ †Tecnología de Alimentos/Elikagaien Teknologia, Facultad de Farmacia/Farmazi Fakultatea, Universidad del País Vasco/Euskal Herriko \\ Unibertsitatea, 01006 Vitoria-Gasteiz, Spain
}

\begin{abstract}
The effect of high-pressure treatment on the volatile profile of ewe milk cheeses was investigated. Cheeses were submitted to $200,300,400$ and $500 \mathrm{MPa}$ at 2 stages of ripening (after 1 and $15 \mathrm{~d}$ of manufacturing) and volatile compounds were assayed at 15 and $60 \mathrm{~d}$ of ripening. High-pressure treatment altered the balance of volatile profile of cheeses, limiting the formation of acids, alcohols, ketones, aldehydes, and sulfur compounds and enhancing the formation of 2,3-butanedione. In general, cheeses pressurized at $15 \mathrm{~d}$ of ripening were more similar to untreated cheeses than those treated at $1 \mathrm{~d}$. Cheeses treated at $300 \mathrm{MPa}$ after $1 \mathrm{~d}$ of manufacturing were characterized by higher levels of free amino acids, ethanol, ethyl esters, and branchedchain aldehydes, whereas cheeses treated at $500 \mathrm{MPa}$ after $1 \mathrm{~d}$ of manufacturing had lower microbial populations, showed the highest abundance of 2,3-butanedione, pyruvaldehyde, and methyl ketones, and the lowest abundance of alcohols.
\end{abstract}

Key words: ewe milk cheese, volatile compound, highpressure treatment

\section{INTRODUCTION}

The volatile flavor compounds constitute one of the most important criteria in determining cheese quality. Their formation and significance in cheeses have been the object of different reviews (Curioni and Bosset, 2002; Marilley and Casey, 2004). The flavor of matured cheese is the result of the interaction of endogenous milk enzymes, rennet enzymes, starter bacteria, and secondary microbiota on milk fat, protein, and carbohydrates (Urbach, 1997), which are developed during ripening. The metabolism of lactate and citrate releases low-weight molecular compounds such as hydroxyl ketones, methyl ketones, and secondary alcohols

Received May 11, 2006.

Accepted June 21, 2006.

${ }^{1}$ Corresponding author: Toni.Trujillo@uab.es
(McSweeney and Sousa, 2000). Lipolysis releases shortchain FFA that are important, or even predominant, components of the flavor of many types of ewe and goat milk cheeses (Barron et al., 2005). The catabolism of FFA contributes to the formation of ketones and related secondary alcohols, lactones, aldehydes, and related primary alcohols, alkanes, and esters (Collins et al., 2003). Proteolysis results in an increase of free amino acids, which are the substrate for catabolic reactions that produce volatile amines and amides, aldehydes, and related alcohols, acids, phenols, and sulfur compounds.

Ripening of cheese is a long and costly process because of capital immobilization, large investment for ripening facilities, and weight losses; consequently, new approaches to ripening acceleration have been attempted. High-pressure (HP) treatment of milk and cheese has been investigated in view of its potential applications in the dairy industry (Trujillo et al., 2002). A further area of interest for HP technology is the acceleration of cheese ripening. A patent by Yokohama et al. (1992) using $50 \mathrm{MPa}$ for $72 \mathrm{~h}$ on Cheddar cheese reported equivalent free amino acid levels to that of a 6-mo-old untreated cheese. The possibility for accelerating the ripening of commercial Cheddar cheese by HP treatment of $50 \mathrm{MPa}$ for $3 \mathrm{~d}$ at $25^{\circ} \mathrm{C}$ at different stages of ripening was further investigated by O'Reilly et al. (2000). These authors concluded that the increases in rates of proteolysis obtained after treatment were not as suggested by Yokohama et al. (1992), possibly due to notable differences in the manufacture of Japanese cheese. Furthermore, the same pressure treatment applied in goat milk cheese slightly increased the proteolysis of cheeses (Saldo et al., 2000). However, higher pressures with short times (400 MPa for $5 \mathrm{~min}$ ) produced twice the levels of free amino acids in pressurized goat milk cheeses compared with the untreated cheese (Saldo et al., 2002). A treatment of $50 \mathrm{MPa}$ also increased the proteolysis of Camembert (Kolakowski et al., 1998; Reps et al., 1998) and Père Joseph cheeses (Messens et al., 2000). Nevertheless, there was no significant influence of HP on proteolysis of Gouda (Kola- 
kowski et al., 1998; Reps et al., 1998) and Kurpiowsky cheeses (Reps et al., 1998) at any pressure applied. An enhancement of proteolysis in Mozzarella and ewe milk cheeses has been described by means of $200 \mathrm{MPa}$ for 60 min (Johnston and Darcy, 2000) and $300 \mathrm{MPa}$ for 10 min (Juan et al., 2004), respectively. In conclusion, the use of HP treatment seems to be useful for cheese ripening acceleration, but it is necessary to find the optimum treatment conditions for each cheese variety.

High-pressure technology could reduce cheese microbiota, modify the ripening indices, rheology, microstructure, and sensory characteristics of cheeses (O'Reilly et al., 2001). The subsequent development of cheese flavor (and therefore, consumer acceptance) may be affected. However, few works have been dedicated to study the effect of HP treatment on the volatile profiles of cheeses. Butz et al. (2000) found lower concentrations of n-butanoic acid and 3-hydroxy-2-butanone in pressurized Gouda cheese, whereas Saldo et al. (2003) described lower amounts of FFA in pressurized goat milk cheeses. According to Jin and Harper (2003), a treatment of $550 \mathrm{MPa}$ for 30 min retarded the fermentation process and ripening, and reduced volatile compound formation in Swiss cheese slurries. More recently, Ávila et al. (2006) studied the effect of HP treatment (400 $\mathrm{MPa}$ for $10 \mathrm{~min}$ ) applied to 15-d-old Hispánico cheeses, and described the increase and decrease of different volatile compounds. Those authors concluded that HP limited the formation of volatile compounds, decreasing the odor quality of cheeses.

The aim of the present study was to determine the influence of $\mathrm{HP}$ on the formation of volatile compounds in ewe milk cheeses during ripening.

\section{MATERIALS AND METHODS}

\section{Cheese Manufacture}

Cheeses $(\sim 0.5 \mathrm{~kg})$ were manufactured in 2 independent experiments from pasteurized $\left(75.5^{\circ} \mathrm{C}, 1 \mathrm{~min}\right)$ ewe milk. Milk was warmed to $38^{\circ} \mathrm{C}$ and a $1 \%$ starter culture (Lactococcus lactis ssp. cremoris, L. lactis ssp. lactis, L. lactis ssp. lactis biovar diacetylactis; Sacco SRL, CO, Italia), $0.05 \%$ (wt/vol) of $\mathrm{CaCl}_{2}$, and $0.01 \%$ of lysozyme were added. Twenty minutes later, $0.02 \%$ ( $\mathrm{vol} / \mathrm{vol}$ ) of calf rennet (Renifor-10, $520 \mathrm{mg}$ of chymosin/L, Lamirsa, Barcelona, Spain) was added. Temperature of coagulation was held at $38^{\circ} \mathrm{C}$ and lasted about $30 \mathrm{~min}$. The coagulum was cut into 8- to 10 -mm cubes and the curd was drained, molded, pressed $(45 \mathrm{~min}$ at $1.2 \mathrm{kPa}, 45$ min at $1.8 \mathrm{kPa}, 45 \mathrm{~min}$ at $2.45 \mathrm{kPa}$, and $1 \mathrm{~h}$ at $3.1 \mathrm{kPa}$ ), and salted by immersion in brine $(20 \% \mathrm{NaCl}$ solution) for $2 \mathrm{~h}$. Cheeses were ripened in a room at $12^{\circ} \mathrm{C}$ and $85 \%$ relative humidity for $60 \mathrm{~d}$.

\section{High-Pressure Treatment}

Cheeses were packed into vacuum pouches, vacuumsealed, and pressure-treated in a batch isostatic press (GEC Alsthom ACB, Nantes, France) at 200, 300, 400, or $500 \mathrm{MPa}$ for $10 \mathrm{~min}$ at $12^{\circ} \mathrm{C}$. One group of cheeses was treated on the first day after manufacture and the others after $15 \mathrm{~d}$ of ripening. Untreated cheeses were used as a control.

To simplify the treatment names, cheeses were coded with a number (2 to 5), indicating the HP treatment applied, followed by P1, if the treatment was applied at d 1 (cheeses $2 \mathbf{P 1}, \mathbf{3 P 1}, \mathbf{4 P 1}$, and $\mathbf{5 P 1}$ ), or P15, if the treatment was applied at d 15 of ripening $(\mathbf{2 P 1 5}, \mathbf{3 P 1 5}$, 4P15, and 5P15).

\section{Cheese Composition and Microbiological Analysis}

Triplicate samples were assayed for total solids (IDF, 1982) and total nitrogen (IDF, 1993). The cheese nitrogen was fractioned according to the method of Kuchroo and Fox (1982) and the extracts obtained were used to determine soluble nitrogen at $\mathrm{pH}$ 4.6. Total free amino acids (FAA) were determined on the water-soluble nitrogen by the cadmium-ninhydrin method described by Folkertsma and Fox (1992). The $\mathrm{pH}$ was measured with a pH meter (Crison MicropH 2001) on a cheese:distilled water (1:1) slurry. Analyses were performed throughout the ripening period. Microbiological analyses of total counts, lactococci, and lactobacilli were performed as described by Juan et al. (2004).

\section{Analysis of Volatile Compounds}

Cheeses were analyzed for volatile compounds at 15 and $60 \mathrm{~d}$ of ripening. Cheeses were cut into sections, vacuum packed, and stored at $-80^{\circ} \mathrm{C}$ until the day before volatile analysis. Cheese sections were thawed at $4^{\circ} \mathrm{C}$ overnight before volatile analysis.

\section{Solid-Phase Microextraction Sampling}

Samples were prepared by removing $1 \mathrm{~cm}$ from the cheese surface to minimize the sampling of volatile compounds that could have migrated from the environment, and grated to a uniform grain size at 10 to $12^{\circ} \mathrm{C}$. One gram of sample was taken and placed in a 4-mL vial, subsequently sealed with a polytetrafluoroethylene/silicone septa (Supelco, Bellefonte, PA). A 75- $\mu \mathrm{m}$ Carboxen-PDMS fiber (Supelco) in a manual solid-phase microextraction holder was used to concentrate the cheese headspace. Fiber was exposed to the headspace above the sample for $30 \mathrm{~min}$ at $80^{\circ} \mathrm{C}$ and desorbed in the injection port for gas chromatography-mass spectrometry analysis at $280^{\circ} \mathrm{C}$. 


\section{Gas Chromatography-Mass Spectrometry Analysis}

Headspace volatile compounds were analyzed using a MD 8000 series gas chromatograph coupled to a MD 800 mass spectrometer detector (Fison Instruments, Milan, Italy). Data were recorded and analyzed with the Xcalibur version 1.1 software (Thermo Finnigan, Manchester, UK). Analyses were performed using a Supelcowax (Supelco) capillary column $(60 \mathrm{~m} \times 0.25 \mathrm{~mm} \times$ $0.25 \mu \mathrm{m}$ film thickness). Oven temperature was initially held at $40^{\circ} \mathrm{C}$ for $10 \mathrm{~min}$, increased to $110^{\circ} \mathrm{C}$ at a rate of $5^{\circ} \mathrm{C} / \mathrm{min}$ followed by $10^{\circ} \mathrm{C} / \mathrm{min}$ to $240^{\circ} \mathrm{C}$, and finally held at $240^{\circ} \mathrm{C}$ for $15 \mathrm{~min}$. Helium was used as the carrier gas with a flow rate of $1 \mathrm{~mL} / \mathrm{min}$. The split valve was opened $5 \mathrm{~min}$ after injection. The transfer line from the gas chromatograph to the mass spectrometer was held at $250^{\circ} \mathrm{C}$. Detection of the chromatographic peaks was done as described previously by Barron et al. (2005). Peak identification was performed by comparing the mass spectra with the National Bureau of Standards and National Institute of Standards and Technology libraries and by comparison of their retention times with authentic standards when available. Peak areas (arbitrary units) were calculated from the total ion current.

\section{Statistical Analysis}

An ANOVA was performed on cheese composition and volatile compounds by SPSS Win version 12.0 (SPSS Inc., Chicago, IL), using HP and ripening time as the main factors. Mean comparisons were carried out using Student-Newman-Keuls test. The principal components analysis was performed using Statistica software (6.0 version, Statsoft Inc., Tulsa, OK). Kaiser's criterion was used to establish the number of final factors from the general parameters considered.

\section{RESULTS AND DISCUSSION}

\section{Physicochemical and Microbiological Analyses}

Cheeses presented 58.8 and $35.3 \%$ of fat and protein, respectively, on a DM basis. Moisture content decreased during ripening in all cheeses and only minor differences were observed between treatments (Table 1). The $\mathrm{pH}$ values of cheeses increased with pressure (Table 1 ), showing the highest values in $5 \mathrm{P} 1$ cheeses. A significant decrease of total microbial counts (4 log units) was obtained at pressures $\geq 400 \mathrm{MPa}$, and was most pronounced (5 log units) at $500 \mathrm{MPa}$ (Figure 1). The $\mathrm{pH}$ behavior observed in 5P1 cheeses was due to the drastic reduction in lactic acid bacteria, which are responsible for lactose fermentation and the production of lactic acid in the initial stages of ripening. Cheeses pressur-

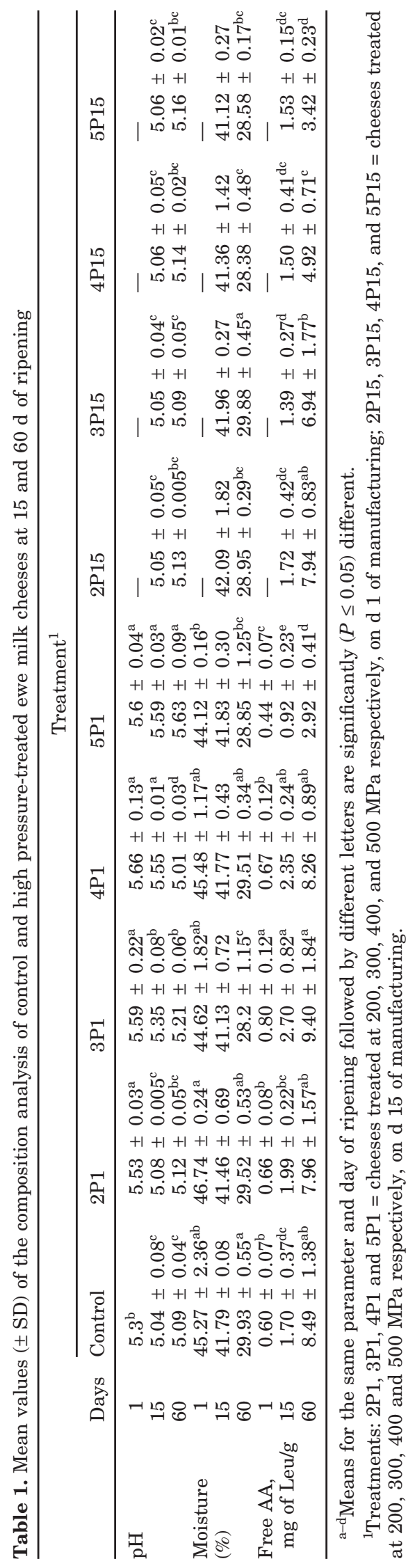



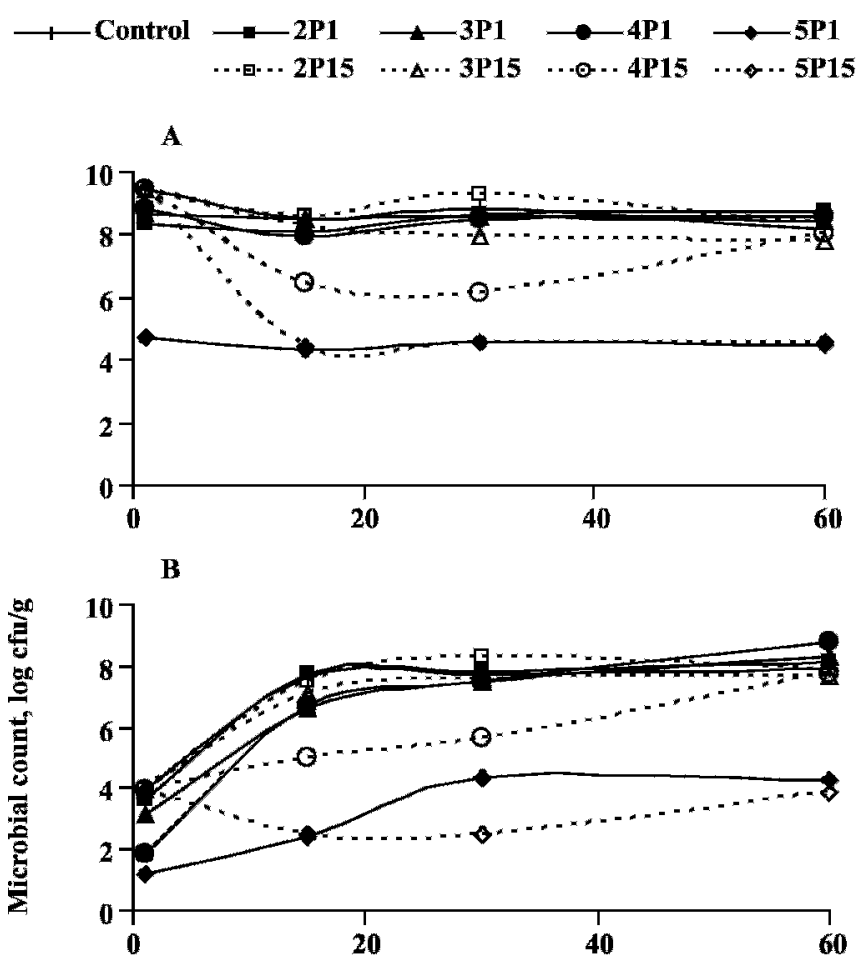

C

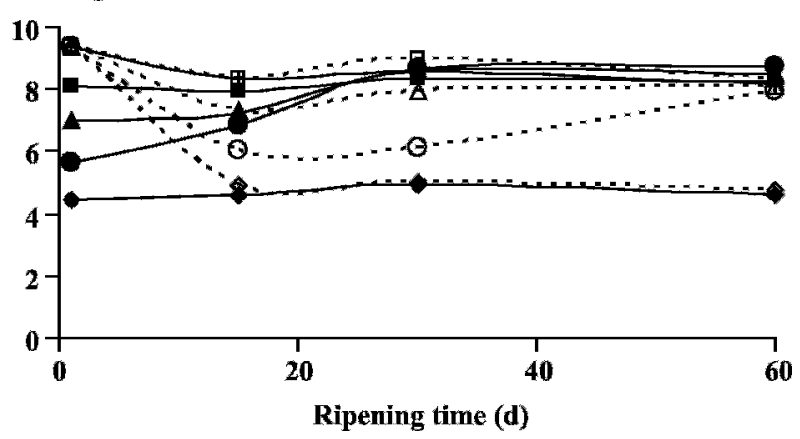

Figure 1. Microbial counts: A) lactococci, B) lactobacilli, and C) total viable counts of control and high pressure-treated ewe milk cheeses during ripening. $2 \mathrm{P} 1,3 \mathrm{P} 1,4 \mathrm{P} 1$, and $5 \mathrm{P} 1$ indicate treatment at $200,300,400$, and $500 \mathrm{MPa}$ at d 1 , respectively; $2 \mathrm{P} 15,3 \mathrm{P} 15,4 \mathrm{P} 15$, and 5P15 indicate the same pressure treatments applied at $\mathrm{d} 15$.

ized at $15 \mathrm{~d}$ of ripening presented similar $\mathrm{pH}$ values to control cheeses, showing that at $15 \mathrm{~d}$ of ripening the acidification process was finished. During ripening, $4 \mathrm{P}$ cheeses recovered their microbial counts, reaching similar values to control cheeses at the end of ripening ( 8 $\log \mathrm{cfu} / \mathrm{g})$. However, counts of $5 \mathrm{P}$ cheeses did not recover during ripening and presented the lowest values (4 log $\mathrm{cfu} / \mathrm{g}$ ) at all times (Figure 1). An increase in the FAA levels was found during ripening (Table 1), with $3 \mathrm{P}$ and $5 \mathrm{P}$ cheeses showing the highest and the lowest levels, respectively. In general, cheeses pressurized on the day of manufacture (d 1) presented higher amounts of FAA than those pressurized at $15 \mathrm{~d}$. The highest values of
FAA were found in $3 \mathrm{P} 1$ cheeses, agreeing with previous observations (Juan et al., 2004).

\section{Volatile Compounds}

Fifty-one compounds were identified in the headspace of the control and HP-treated ewe milk cheeses. Table 2 lists the percentage of the volatile compounds grouped by chemical families in the control and HP-treated cheeses. Compounds were grouped by chemical families including acids, alcohols, aldehydes, ethyl esters, ketones, lactones, and sulfur compounds (Tables 3 to 7). There were also 4 unresolved chromatographic peaks, each peak comprising 2 substances (Table 8).

Cheeses in the $2 \mathrm{P} 1$ group were similar to the control cheeses; however, pressures $\geq 300 \mathrm{MPa}$ considerably changed the volatile profile composition of HP-treated cheeses. At $15 \mathrm{~d}$ of ripening, acids and alcohols were the most abundant volatile compounds in control cheeses; however, abundance of these compounds decreased with the increase of pressure. The percentage of aldehydes increased in HP-treated cheeses, and they were the main volatile compounds in $4 \mathrm{P} 1$ and $5 \mathrm{P} 1$ cheeses. A considerable percentage of ketones were found in $3 \mathrm{P} 1$, $4 \mathrm{P} 1$, and $5 \mathrm{P} 1$ cheeses; this was related to the increase in the levels of 2,3-butanedione found in these cheeses (Table 7). At $60 \mathrm{~d}$ of ripening, $4 \mathrm{P}$ and $5 \mathrm{P}$ cheeses showed an enormous decrease in the percentages of the alcohols, whereas aldehydes and ketones increased. Esters, lactones, and sulfur compounds were detected in very low percentages in all cheeses; however, the percentage of esters increased considerably in $3 \mathrm{P} 1$ cheeses at the end of ripening.

Acids. Acids, particularly short-chain fatty acids, are produced primarily by lipolysis. However, n-butanoic and ethanoic acids may also be produced by fermentation of lactose and lactic acid (Ortigosa et al., 2001). Deamination of amino acids and possibly lipid oxidation may also contribute to the overall acid pool (Corrëa Lelles Nogueira et al., 2005). The contribution of acids to aroma development has been demonstrated in many matured cheese varieties (Ortigosa et al., 2001; Saldo et al., 2003; Barron et al., 2005). n-Butanoic acid is one of the most important short-chain FFA responsible for the flavor in ewe milk cheeses and, like n-hexanoic acid, is characterized as having a strong and pungent cheese note (Moio and Addeo, 1998). n-Pentanoic acid has been detected as a mild to strong savory cheese aroma (Frank et al., 2004), whereas ethanoic acid is characterized as having a vinegar pungent note (Frank et al., 2004) and correlated positively with sweetness and burnt-aftertaste flavor in hard-type cheeses (Lawlor et al., 2002). Acids also act as precursor molecules for a series of catabolic reactions, which lead to the productions of 


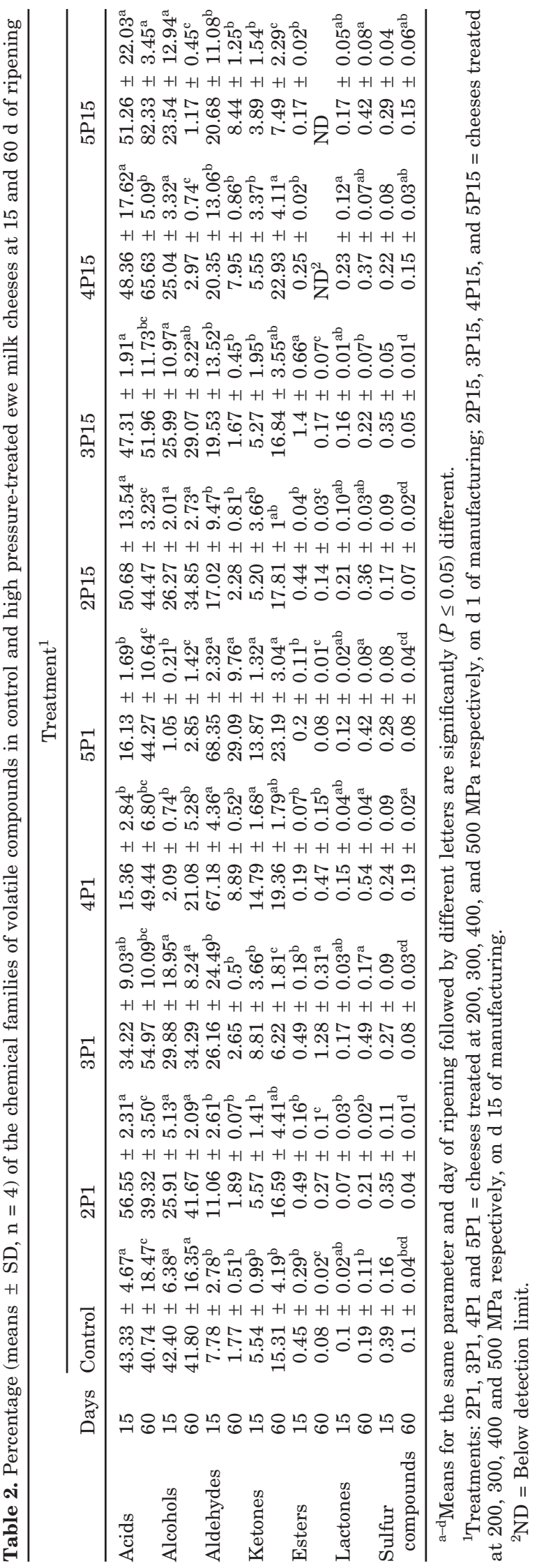

other flavor compounds such as secondary alcohols, lactones, and methyl ketones (Collins et al., 2003).

The abundance of total acids increased with cheese age (Table 3). Ethanoic and n-butanoic acids were the main acids found at 15 and $60 \mathrm{~d}$ of ripening, respectively. In general, 4P1 and 5P1 cheeses showed a decrease in the acids levels, whereas all P15 cheeses had similar levels to control cheeses. A decrease in the concentration of $n$-butanoic acid was observed in an HPtreated Gouda cheese (Butz et al., 2000) and was associated with the effect of HP on the enzymes involved in the lactose fermentation. Furthermore, Saldo et al. (2003) reported lower levels of n-butanoic, n-hexanoic, and n-octanoic acids in a goat milk cheese treated at $400 \mathrm{MPa}$; this was attributed to the lower lactococci counts and inactivation of bacterial enzymes by the HP treatment.

Alcohols. Alcohols are produced by the reduction of their corresponding aldehydes and methyl ketones through the activity of lactic acid bacteria dehydrogenases or by chemical reactions (Molimard and Spinnler, 1996). Ethanol, the most abundant primary alcohol in our cheeses, is formed primarily by lactose fermentation (Ortigosa et al., 2001), although it can also be formed from Ala by Strecker degradation and ethanal reduction (Molimard and Spinnler, 1996).

The HP treatments carried out at $\geq 400 \mathrm{MPa}$ had a clear effect on alcohols, producing a significant $(P \leq$ 0.05 ) decrease in the abundance of ethanol, 2-pentanol, 2-hexanol, 2-heptanol, 2-butanol, and 2,3-butanediol (Table 4). The moment when the HP treatment was applied was also significant, with the P15 cheeses presenting lower levels of ethanol, 2-pentanol, 2-hexanol, and 2-heptanol compared with control and P1 cheeses at $60 \mathrm{~d}$ of ripening. As was previously explained, pressures $\geq 400 \mathrm{MPa}$ caused a decrease in lactic acid bacteria counts (Figure 1), which are the responsible to lactose fermentation, and therefore, could explain the low amounts of ethanol found in 4P1 and 5P1 cheeses. Furthermore, these treatments could affect the activity of the enzyme involved in the reduction from methyl ketones to secondary alcohols. The highest level of ethanol was found in 3P1 cheeses; this may be related to the higher amounts of FAA found in these cheeses (Figure 2), thus favoring ethanol formation by Ala degradation. The abundances of 1-propanol, 1-butanol, and 1-hexanol increased significantly during ripening (Table 4), but they were undetected in $5 \mathrm{P} 15$ cheeses at $60 \mathrm{~d}$ of ripening.

2,3-Butanediol, generated from citrate by reduction of 2,3-butanedione by the starter bacteria, can be converted to 2-butanone by some strains of lactobacilli, and finally reduced to 2-butanol. High pressure-treated 
Table 3. Abundance ${ }^{1}$ of acids detected in the volatile fraction of ewe milk cheeses

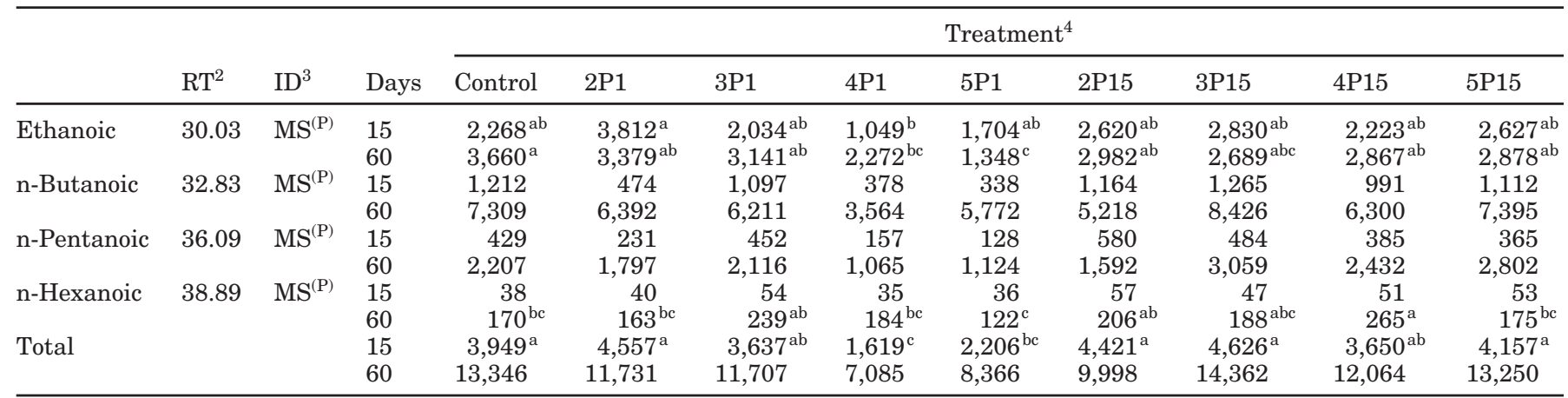

${ }^{\mathrm{a}-\mathrm{c}}$ Means $(\mathrm{n}=4)$ for the same row followed by different letters are significantly $(P \leq 0.05)$ different.

${ }^{1}$ Integrated area counts.

${ }^{2}$ Retention time (min).

${ }^{3}$ Identification: MS = Mass spectra, ${ }^{(\mathrm{P})}$ Positively identified by comparison with RT and MS of authentic standards. All components were quantified with total ion chromatogram.

${ }^{4}$ Treatments: 2P1, 3P1, 4P1 and 5P1 = cheeses treated at 200, 300, 400, and $500 \mathrm{MPa}$ respectively, on d 1 of manufacturing; 2P15, 3P15, $4 \mathrm{P} 15$, and $5 \mathrm{P} 15=$ cheeses treated at 200, 300, 400 and $500 \mathrm{MPa}$ respectively, on d 15 of manufacturing.

cheeses presented lower levels of 2,3-butanediol than did control cheeses, being undetectable in 4P1 and 5P1 cheeses, which could be explained by the effect of HP on 2,3-butanediol dehydrogenase. Furthermore, contents of 2-butanol decreased in HP cheeses treated at pressures $\geq 400 \mathrm{MPa}$, in agreement with the lower levels

Table 4. Abundance ${ }^{1}$ of alcohols detected in the volatile fraction of ewe milk cheeses

\begin{tabular}{|c|c|c|c|c|c|c|c|c|c|c|c|c|}
\hline & \multirow[b]{2}{*}{$\mathrm{RT}^{2}$} & \multirow[b]{2}{*}{$\mathrm{ID}^{3}$} & \multirow[b]{2}{*}{ Days } & \multicolumn{9}{|c|}{ Treatment $^{4}$} \\
\hline & & & & Control & 2P1 & 3P1 & 4P1 & $5 \mathrm{P} 1$ & 2P15 & $3 \mathrm{P} 15$ & $4 \mathrm{P} 15$ & $5 \mathrm{P} 15$ \\
\hline \multirow[t]{2}{*}{ Ethanol } & \multirow[t]{2}{*}{8.63} & \multirow{2}{*}{$\mathrm{MS}^{(\mathrm{P})}$} & 15 & $792^{\mathrm{ab}}$ & $486^{\mathrm{ab}}$ & $1,696^{\mathrm{a}}$ & $160^{\mathrm{b}}$ & $113^{\mathrm{b}}$ & $712^{\mathrm{ab}}$ & $790^{\mathrm{ab}}$ & $601^{\mathrm{ab}}$ & $166^{\mathrm{b}}$ \\
\hline & & & 60 & $729^{c}$ & $742^{\mathrm{c}}$ & $2,438^{\mathrm{a}}$ & $1,336^{\mathrm{b}}$ & $212^{\mathrm{c}}$ & $325^{c}$ & $495^{c}$ & $168^{c}$ & $123^{c}$ \\
\hline \multirow{2}{*}{ 1-Propanol } & \multirow{2}{*}{14.03} & \multirow{2}{*}{$\mathrm{MS}^{(\mathrm{P})}$} & 15 & ND & $\mathrm{ND}$ & ND & ND & ND & ND & ND & ND & ND \\
\hline & & & 60 & $55^{\mathrm{ab}}$ & $57^{\mathrm{ab}}$ & $50^{\mathrm{ab}}$ & $14^{\mathrm{bc}}$ & $\mathrm{ND}^{\mathrm{c}}$ & $49^{\mathrm{ab}}$ & $64^{\mathrm{a}}$ & $15^{\mathrm{bc}}$ & $\mathrm{ND}^{\mathrm{c}}$ \\
\hline \multirow[t]{2}{*}{ 1-Butanol } & \multirow[t]{2}{*}{19.29} & \multirow[t]{2}{*}{$\mathrm{MS}^{(\mathrm{P})}$} & 15 & ND & ND & ND & ND & ND & ND & ND & ND & ND \\
\hline & & & 60 & $220^{\mathrm{ab}}$ & $267^{\mathrm{ab}}$ & $135^{\mathrm{ab}}$ & $37^{\mathrm{b}}$ & $102^{\mathrm{ab}}$ & $191^{\mathrm{ab}}$ & $438^{a}$ & $124^{\mathrm{ab}}$ & ND \\
\hline \multirow[t]{2}{*}{ 1-Hexanol } & \multirow[t]{2}{*}{26.76} & \multirow[t]{2}{*}{$\mathrm{MS}^{(\mathrm{P})}$} & 15 & $11^{\mathrm{bc}}$ & $5^{c}$ & $19^{\mathrm{ab}}$ & $18^{a b}$ & $\mathrm{ND}^{\mathrm{c}}$ & $20^{\mathrm{ab}}$ & $28^{\mathrm{a}}$ & $5^{\mathrm{c}}$ & $3^{c}$ \\
\hline & & & 60 & $49^{\mathrm{ab}}$ & $102^{\mathrm{ab}}$ & $44^{\mathrm{ab}}$ & $68^{\mathrm{ab}}$ & $167^{\mathrm{a}}$ & $54^{\mathrm{ab}}$ & $87^{\mathrm{ab}}$ & $31^{\mathrm{b}}$ & $\mathrm{ND}^{\mathrm{b}}$ \\
\hline \multirow[t]{2}{*}{ 2-Butanol } & \multirow[t]{2}{*}{13.43} & \multirow[t]{2}{*}{$\mathrm{MS}^{(\mathrm{P})}$} & 15 & $45^{\mathrm{a}}$ & $14^{\mathrm{b}}$ & $57^{\mathrm{a}}$ & $\mathrm{ND}^{\mathrm{b}}$ & $\mathrm{ND}^{\mathrm{b}}$ & $49^{\mathrm{a}}$ & $\mathrm{ND}^{\mathrm{b}}$ & $\mathrm{ND}^{\mathrm{b}}$ & $\mathrm{ND}^{\mathrm{b}}$ \\
\hline & & & 60 & $8,968^{a}$ & $9,124^{\mathrm{a}}$ & $2,697^{\mathrm{c}}$ & $294^{\mathrm{c}}$ & $\mathrm{ND}^{\mathrm{c}}$ & $6,625^{\mathrm{b}}$ & $5,960^{\mathrm{b}}$ & $143^{\mathrm{c}}$ & $\mathrm{ND}^{\mathrm{c}}$ \\
\hline \multirow[t]{2}{*}{ 2-Pentanol } & \multirow[t]{2}{*}{18.26} & \multirow[t]{2}{*}{$\mathrm{MS}^{(\mathrm{P})}$} & 15 & $68^{a}$ & $56^{\mathrm{a}}$ & $71^{\mathrm{a}}$ & $14^{\mathrm{bc}}$ & $\mathrm{ND}^{\mathrm{c}}$ & $41^{\mathrm{ab}}$ & $60^{a}$ & $12^{\mathrm{bc}}$ & $26^{b c}$ \\
\hline & & & 60 & $4,579^{a}$ & $1,495^{\mathrm{ab}}$ & $1,103^{\mathrm{ab}}$ & $952^{\mathrm{ab}}$ & $77^{\mathrm{b}}$ & $404^{\mathrm{b}}$ & $123^{\mathrm{b}}$ & $29^{b}$ & $38^{b}$ \\
\hline \multirow[t]{2}{*}{ 2-Hexanol } & \multirow[t]{2}{*}{22.29} & \multirow[t]{2}{*}{$\mathrm{MS}^{(\mathrm{T})}$} & 15 & ND & ND & ND & ND & ND & ND & ND & ND & ND \\
\hline & & & 60 & $19^{a b c}$ & $28^{\mathrm{a}}$ & $22^{\mathrm{ab}}$ & $12^{\mathrm{cd}}$ & $13^{\mathrm{bcd}}$ & $9^{\text {de }}$ & $\mathrm{ND}^{\mathrm{e}}$ & $\mathrm{ND}^{\mathrm{e}}$ & $\mathrm{ND}^{\mathrm{e}}$ \\
\hline \multirow[t]{2}{*}{ 2-Heptanol } & \multirow[t]{2}{*}{25.76} & \multirow[t]{2}{*}{$\mathrm{MS}^{(\mathrm{P})}$} & 15 & $26^{\mathrm{ab}}$ & $25^{\mathrm{ab}}$ & $40^{\mathrm{a}}$ & ND & ND & $28^{a b}$ & $27^{\mathrm{ab}}$ & $18^{\mathrm{ab}}$ & $6^{\mathrm{b}}$ \\
\hline & & & 60 & $395^{\mathrm{b}}$ & $599^{a}$ & $546^{\mathrm{a}}$ & $77^{\mathrm{c}}$ & $37^{\mathrm{c}}$ & $129^{c}$ & $99^{c}$ & $17^{\mathrm{c}}$ & $17^{\mathrm{c}}$ \\
\hline \multirow[t]{2}{*}{ 2,3-Butanediol } & \multirow[t]{2}{*}{32.06} & $\mathrm{MS}^{(\mathrm{T})}$ & 15 & $2,966^{\mathrm{a}}$ & $1,608^{a b}$ & $1,103^{\mathrm{ab}}$ & $\mathrm{ND}^{\mathrm{b}}$ & $\mathrm{ND}^{\mathrm{b}}$ & $1,620^{\mathrm{ab}}$ & $1,590^{\mathrm{ab}}$ & $1,495^{\mathrm{ab}}$ & $2,174^{\mathrm{ab}}$ \\
\hline & & & 60 & ND & ND & ND & ND & ND & ND & ND & ND & ND \\
\hline 3-Methyl-1-butanol & 21.83 & $\mathrm{MS}^{(\mathrm{P})}$ & 15 & $21^{\mathrm{ab}}$ & $13^{\mathrm{b}}$ & $21^{\mathrm{ab}}$ & $16^{\mathrm{b}}$ & $23^{\mathrm{ab}}$ & $23^{\mathrm{ab}}$ & $40^{\mathrm{a}}$ & $16^{\mathrm{b}}$ & $8^{b}$ \\
\hline & & & 60 & $12^{\mathrm{cd}}$ & $16^{\mathrm{cd}}$ & $12^{\mathrm{cd}}$ & $31^{\mathrm{a}}$ & $26^{\mathrm{ab}}$ & $7^{\mathrm{cd}}$ & $12^{\text {cd }}$ & $12^{\mathrm{cd}}$ & $\mathrm{ND}^{\mathrm{c}}$ \\
\hline 2-Propen-1-ol & 18.06 & $\mathrm{MS}^{(\mathrm{T})}$ & 15 & ND & ND & $\mathrm{ND}$ & ND & $\mathrm{ND}$ & ND & ND & ND & $\mathrm{ND}$ \\
\hline & & & 60 & $40^{\mathrm{c}}$ & $21^{\mathrm{cd}}$ & $\mathrm{ND}^{\mathrm{d}}$ & $\mathrm{ND}^{\mathrm{d}}$ & $\mathrm{ND}^{\mathrm{d}}$ & $112^{\mathrm{a}}$ & $83^{b}$ & $29^{\text {cd }}$ & $\mathrm{ND}^{\mathrm{d}}$ \\
\hline Total & & & 15 & $3,929^{\mathrm{a}}$ & $2,207^{\mathrm{ab}}$ & $2,988^{\mathrm{ab}}$ & $190^{\mathrm{b}}$ & $136^{\mathrm{b}}$ & $2,493^{\mathrm{ab}}$ & $2,535^{\mathrm{ab}}$ & $2,147^{\mathrm{ab}}$ & $2,383^{\mathrm{ab}}$ \\
\hline & & & 60 & $15,066^{\mathrm{a}}$ & $12,451^{\mathrm{ab}}$ & $7,047^{\mathrm{ab}}$ & $2,784^{\mathrm{cd}}$ & $634^{\mathrm{d}}$ & $7,905^{\mathrm{bc}}$ & $7,361^{\mathrm{bc}}$ & $568^{\mathrm{d}}$ & $178^{\mathrm{d}}$ \\
\hline
\end{tabular}

${ }^{\mathrm{a}-\mathrm{e}}$ Means $(\mathrm{n}=4)$ for the same row followed by different letters are significantly $(P \leq 0.05)$ different.

${ }^{1}$ Integrated area counts; ND = below detection limit.

${ }^{2}$ Retention time (min).

${ }^{3}$ Identification: MS = Mass spectra, ${ }^{(T)}$ Tentatively identifies on the basis of the NBS and NIST libraries, ${ }^{(\mathrm{P})}$ Positively identified by comparison with RT and MS of authentic standards. All components were quantified with total ion chromatogram.

${ }^{4}$ Treatments: $2 \mathrm{P} 1,3 \mathrm{P} 1,4 \mathrm{P} 1$ and $5 \mathrm{P} 1$ = cheeses treated at 200, 300, 400, and $500 \mathrm{MPa}$ respectively, on d 1 of manufacturing; $2 \mathrm{P} 15$, 3P15, $4 \mathrm{P} 15$, and $5 \mathrm{P} 15$ = cheeses treated at 200, 300, 400 and $500 \mathrm{MPa}$ respectively, on d 15 of manufacturing. 
Table 5. Abundance ${ }^{1}$ of aldehydes detected in the volatile fraction of ewe milk cheeses

\begin{tabular}{|c|c|c|c|c|c|c|c|c|c|c|c|c|}
\hline & \multirow[b]{2}{*}{$\mathrm{RT}^{2}$} & \multirow[b]{2}{*}{$\mathrm{ID}^{3}$} & \multirow[b]{2}{*}{ Days } & \multicolumn{9}{|c|}{ Treatment $^{4}$} \\
\hline & & & & Control & $2 \mathrm{P} 1$ & 3P1 & $4 \mathrm{P} 1$ & $5 \mathrm{P} 1$ & $2 \mathrm{P} 15$ & $3 \mathrm{P} 15$ & $4 \mathrm{P} 15$ & $5 \mathrm{P} 15$ \\
\hline Ethanal & 3.99 & $\mathrm{MS}^{(\mathrm{P})}$ & 15 & $504^{\mathrm{ab}}$ & $581^{\mathrm{a}}$ & $314^{\mathrm{ab}}$ & $282^{\mathrm{ab}}$ & $214^{\mathrm{b}}$ & $448^{\mathrm{ab}}$ & $466^{\mathrm{ab}}$ & $424^{\mathrm{ab}}$ & $572^{\mathrm{a}}$ \\
\hline Benzaldehyde & 31.13 & $\mathrm{MS}^{(\mathrm{T})}$ & 15 & 18 & 14 & 20 & 21 & 20 & 16 & 9 & 11 & 12 \\
\hline \multirow[t]{2}{*}{ Pyruvaldehyde } & 25.13 & $\mathrm{MS}^{(\mathrm{T})}$ & $\begin{array}{l}60 \\
15\end{array}$ & $\begin{array}{l}30^{\mathrm{d}} \\
81^{\mathrm{b}}\end{array}$ & $\begin{array}{l}40^{\mathrm{cd}} \\
72^{\mathrm{b}}\end{array}$ & $\begin{array}{r}98^{\mathrm{a}} \\
2,809^{\mathrm{b}}\end{array}$ & $\begin{array}{c}72^{\mathrm{b}} \\
6,899^{\mathrm{ab}}\end{array}$ & $\begin{array}{r}72^{\mathrm{b}} \\
8,600^{\mathrm{a}}\end{array}$ & $\begin{array}{c}40^{\mathrm{cd}} \\
1,327^{\mathrm{b}}\end{array}$ & $\begin{array}{r}25^{\mathrm{d}} \\
1,391^{\mathrm{b}}\end{array}$ & $\begin{array}{r}59^{\mathrm{bc}} \\
1,604^{\mathrm{b}}\end{array}$ & $\begin{array}{r}79^{\mathrm{ab}} \\
1,400^{\mathrm{b}}\end{array}$ \\
\hline & & & 60 & $36^{\mathrm{b}}$ & $36^{\mathrm{b}}$ & $33^{\mathrm{b}}$ & $475^{\mathrm{b}}$ & $5495^{\mathrm{a}}$ & $\mathrm{ND}^{\mathrm{b}}$ & $\mathrm{ND}^{\mathrm{b}}$ & $106^{\mathrm{b}}$ & $813^{\mathrm{b}}$ \\
\hline \multirow[t]{2}{*}{ 2-Methyl-butanal } & 7.66 & $\mathrm{MS}^{(\mathrm{T})}$ & 15 & $10^{\mathrm{ab}}$ & $10^{\mathrm{ab}}$ & $14^{\mathrm{a}}$ & $7^{\mathrm{ab}}$ & $\mathrm{ND}^{\mathrm{c}}$ & $7^{\mathrm{abc}}$ & $6^{\mathrm{abc}}$ & $5^{\mathrm{bc}}$ & $8^{a b}$ \\
\hline & & & 60 & $10^{\mathrm{b}}$ & $9^{b}$ & $89^{a}$ & $12^{\mathrm{b}}$ & $\mathrm{ND}^{\mathrm{b}}$ & $8^{\mathrm{b}}$ & $10^{\mathrm{b}}$ & $7^{\mathrm{b}}$ & $13^{\mathrm{b}}$ \\
\hline \multirow[t]{2}{*}{ 3-Methyl-butanal } & 7.83 & $\mathrm{MS}^{(\mathrm{T})}$ & 15 & 50 & 54 & 54 & 54 & 24 & 44 & 41 & 36 & 47 \\
\hline & & & 60 & 72 & 60 & 86 & 65 & 54 & 49 & 37 & 60 & 90 \\
\hline \multirow[t]{2}{*}{ 2-Methyl-pentanal } & 27.82 & $\mathrm{MS}^{(\mathrm{T})}$ & 15 & $24^{\mathrm{b}}$ & $99^{\mathrm{a}}$ & $63^{\mathrm{ab}}$ & $43^{\mathrm{ab}}$ & $31^{\mathrm{b}}$ & $19^{\mathrm{b}}$ & $15^{\mathrm{b}}$ & $8^{\mathrm{b}}$ & $13^{\mathrm{b}}$ \\
\hline & & & 60 & 77 & 64 & 127 & 106 & 100 & 120 & 101 & 38 & 55 \\
\hline Total & & & 15 & $703^{c}$ & $836^{\mathrm{c}}$ & $3,284^{\mathrm{bc}}$ & $7,316^{\mathrm{ab}}$ & $8,900^{\mathrm{a}}$ & $1,872^{\mathrm{c}}$ & $1,936^{\mathrm{c}}$ & $2,095^{\mathrm{c}}$ & $2,061^{\mathrm{c}}$ \\
\hline
\end{tabular}

${ }^{\mathrm{a}-\mathrm{d}}$ Means $(\mathrm{n}=4)$ for the same row followed by different letters are significantly $(P \leq 0.05)$ different.

${ }^{1}$ Integrated area counts; ND = below detection limit.

${ }^{2}$ Retention time (min).

${ }^{3}$ Identification: MS = Mass spectra, ${ }^{(\mathrm{T})}$ Tentatively identifies on the basis of the NBS and NIST libraries, ${ }^{(\mathrm{P})}$ Positively identified by comparison with RT and MS of authentic standards. All components were quantified with total ion chromatogram.

${ }^{4}$ Treatments: 2P1, 3P1, 4P1 and 5P1 = cheeses treated at 200, 300, 400, and $500 \mathrm{MPa}$ respectively, on d 1 of manufacturing; 2P15, 3P15, $4 \mathrm{P} 15$, and $5 \mathrm{P} 15$ = cheeses treated at 200, 300, 400 and $500 \mathrm{MPa}$ respectively, on d 15 of manufacturing.

of 2,3-butanediol and 2-butanone found in these cheeses.

Levels of 3-methyl-1-butanol did not change significantly $(P>0.05)$ during ripening (Table 4$)$. Law (1982) described a slightly sweet, fresh flavor of many soft cheeses attributed to this compound, whereas fruity, alcohol, and winey overtones (Moio and Addeo, 1998) are attributed to 3-methyl-1-butanol. Lower levels of 3- methyl-1-butanol were found in our cheeses, the lowest being found in $5 \mathrm{P} 15$ cheeses. The HP treatment reduced the abundances of total alcohols, with $4 \mathrm{P}$ and $5 \mathrm{P}$ cheeses showing the lowest levels at the end of ripening.

Aldehydes. The abundance of the total aldehydes was influenced by the HP treatment (Table 5). Pressures $\geq 400 \mathrm{MPa}$ caused a slight decrease in the ethanal levels and a significant $(P \leq 0.05)$ increase in pyruvalde-

Table 6. Abundance ${ }^{1}$ of esters detected in the volatile fraction of ewe milk cheeses

\begin{tabular}{|c|c|c|c|c|c|c|c|c|c|c|c|c|}
\hline & \multirow[b]{2}{*}{$\mathrm{RT}^{2}$} & \multirow[b]{2}{*}{$\mathrm{ID}^{3}$} & \multirow[b]{2}{*}{ Days } & \multicolumn{9}{|c|}{ Treatment $^{4}$} \\
\hline & & & & Control & $2 \mathrm{P} 1$ & $3 \mathrm{P} 1$ & $4 \mathrm{P} 1$ & $5 \mathrm{P} 1$ & $2 \mathrm{P} 15$ & $3 \mathrm{P} 15$ & $4 \mathrm{P} 15$ & $5 \mathrm{P} 15$ \\
\hline \multirow[t]{2}{*}{ Ethyl ethanoate } & \multirow[t]{2}{*}{6.83} & \multirow[t]{2}{*}{$\mathrm{MS}^{(\mathrm{T})}$} & 15 & 32 & 39 & 36 & 18 & 29 & 34 & 48 & 21 & 15 \\
\hline & & & 60 & $29^{\mathrm{b}}$ & $39^{\mathrm{b}}$ & $101^{\mathrm{a}}$ & $34^{\mathrm{b}}$ & $16^{\mathrm{b}}$ & $16^{\mathrm{b}}$ & $27^{\mathrm{b}}$ & $\mathrm{ND}^{\mathrm{b}}$ & $\mathrm{ND}^{\mathrm{b}}$ \\
\hline \multirow{2}{*}{ Ethyl hexanoate } & \multirow{2}{*}{22.60} & \multirow[t]{2}{*}{$\mathrm{MS}^{(\mathrm{P})}$} & 15 & $8^{b}$ & $\mathrm{ND}^{\mathrm{b}}$ & $14^{\mathrm{b}}$ & $\mathrm{ND}^{\mathrm{b}}$ & $\mathrm{ND}^{\mathrm{b}}$ & $8^{b}$ & $48^{\mathrm{a}}$ & $\mathrm{ND}^{\mathrm{b}}$ & $\mathrm{ND}^{\mathrm{b}}$ \\
\hline & & & 60 & $\mathrm{ND}^{\mathrm{c}}$ & $41^{\mathrm{b}}$ & $165^{\mathrm{a}}$ & $24^{\mathrm{bc}}$ & $\mathrm{ND}^{\mathrm{c}}$ & $14^{\mathrm{bc}}$ & $22^{\mathrm{bc}}$ & $\mathrm{ND}^{\mathrm{c}}$ & $\mathrm{ND}^{\mathrm{c}}$ \\
\hline \multirow[t]{2}{*}{ Ethyl octanoate } & \multirow[t]{2}{*}{28.86} & \multirow[t]{2}{*}{$\mathrm{MS}^{(\mathrm{P})}$} & 15 & ND & ND & ND & ND & ND & ND & ND & ND & ND \\
\hline & & & 60 & $\mathrm{ND}^{\mathrm{b}}$ & $\mathrm{ND}^{\mathrm{b}}$ & $37^{\mathrm{a}}$ & $\mathrm{ND}^{\mathrm{b}}$ & $\mathrm{ND}^{\mathrm{b}}$ & $\mathrm{ND}^{\mathrm{b}}$ & $\mathrm{ND}^{\mathrm{b}}$ & $\mathrm{ND}^{\mathrm{b}}$ & $\mathrm{ND}^{\mathrm{b}}$ \\
\hline \multirow[t]{2}{*}{ Total } & & & 15 & $40^{\mathrm{b}}$ & $39^{\mathrm{b}}$ & $50^{\mathrm{b}}$ & $18^{\mathrm{b}}$ & $29^{\mathrm{b}}$ & $42^{\mathrm{b}}$ & $96^{\mathrm{a}}$ & $21^{\mathrm{b}}$ & $15^{\mathrm{b}}$ \\
\hline & & & 60 & $29^{b c}$ & $80^{\mathrm{b}}$ & $303^{\mathrm{a}}$ & $58^{\mathrm{bc}}$ & $16^{\mathrm{bc}}$ & $30^{\mathrm{bc}}$ & $49^{\mathrm{bc}}$ & $\mathrm{ND}^{\mathrm{c}}$ & $\mathrm{ND}^{\mathrm{c}}$ \\
\hline
\end{tabular}

${ }^{\mathrm{a}-\mathrm{c}}$ Means $(\mathrm{n}=4)$ for the same row followed by different letters are significantly $(P \leq 0.05)$ different.

${ }^{1}$ Integrated area counts; ND = below detection limit.

${ }^{2}$ Retention time (min).

${ }^{3}$ Identification: MS = Mass spectra, ${ }^{(T)}$ Tentatively identifies on the basis of the NBS and NIST libraries, ${ }^{(\mathrm{P})}$ Positively identified by comparison with RT and MS of authentic standards. All components were quantified with total ion chromatogram.

${ }^{4}$ Treatments: $2 \mathrm{P} 1,3 \mathrm{P} 1,4 \mathrm{P} 1$ and $5 \mathrm{P} 1=$ cheeses treated at 200, 300, 400, and $500 \mathrm{MPa}$ respectively, on d 1 of manufacturing; $2 \mathrm{P} 15,3 \mathrm{P} 15,4 \mathrm{P} 15$, and $5 \mathrm{P} 15$ = cheeses treated at 200, 300, 400 and $500 \mathrm{MPa}$ respectively, on d 15 of manufacturing. 
Table 7. Abundance ${ }^{1}$ of ketones detected in the volatile fraction of ewe milk cheese

\begin{tabular}{|c|c|c|c|c|c|c|c|c|c|c|c|c|}
\hline & \multirow[b]{2}{*}{$\mathrm{RT}^{2}$} & \multirow[b]{2}{*}{$\mathrm{ID}^{3}$} & \multirow[b]{2}{*}{ Days } & \multicolumn{9}{|c|}{ Treatment ${ }^{4}$} \\
\hline & & & & Control & $2 \mathrm{P} 1$ & $3 \mathrm{P} 1$ & $4 \mathrm{P} 1$ & $5 \mathrm{P} 1$ & $2 \mathrm{P} 15$ & $3 \mathrm{P} 15$ & $4 \mathrm{P} 15$ & $5 \mathrm{P} 15$ \\
\hline 2-Propanone & 5.23 & $\mathrm{MS}^{(\mathrm{T})}$ & 15 & 136 & 185 & 96 & 91 & 179 & 130 & 189 & 124 & 74 \\
\hline \multirow[t]{2}{*}{ 2-Butanone } & 7.26 & $\mathrm{MS}^{(\mathrm{P})}$ & 15 & 38 & 38 & 141 & 24 & 23 & 156 & 25 & 100 & 28 \\
\hline & & & 60 & $4,146^{\mathrm{a}}$ & $3,888^{\mathrm{a}}$ & $808^{b}$ & $237^{\mathrm{b}}$ & $31^{\mathrm{b}}$ & $3,381^{\mathrm{a}}$ & $4,069^{\mathrm{a}}$ & $3,665^{\mathrm{a}}$ & $30^{\mathrm{b}}$ \\
\hline \multirow{2}{*}{ 2-Pentanone } & 10.66 & $\mathrm{MS}^{(\mathrm{P})}$ & 15 & $239^{\mathrm{ab}}$ & $132^{\mathrm{b}}$ & $196^{\mathrm{ab}}$ & $390^{\mathrm{a}}$ & $398^{\mathrm{a}}$ & $72^{\mathrm{b}}$ & $234^{\text {cd }}$ & $83^{\mathrm{b}}$ & $104^{\mathrm{b}}$ \\
\hline & & & 60 & $1,059^{\mathrm{c}}$ & $833^{\mathrm{cd}}$ & $398^{\mathrm{cd}}$ & $2,240^{\mathrm{b}}$ & $3,629^{\mathrm{a}}$ & $576^{\mathrm{cd}}$ & $180^{\mathrm{d}}$ & $501^{\mathrm{cd}}$ & $877^{\mathrm{cd}}$ \\
\hline \multirow[t]{2}{*}{ Total } & & & 15 & $509^{\mathrm{b}}$ & $431^{\mathrm{b}}$ & $1,028^{\mathrm{b}}$ & $1,568^{\mathrm{a}}$ & $1,923^{\mathrm{a}}$ & $585^{\mathrm{b}}$ & $512^{\mathrm{b}}$ & $564^{\mathrm{b}}$ & $320^{\mathrm{b}}$ \\
\hline & & & 60 & $5,304^{\mathrm{a}}$ & $4,897^{\mathrm{a}}$ & $1,285^{b c}$ & $2,698^{\mathrm{b}}$ & $4,781^{\mathrm{a}}$ & $4,015^{\mathrm{ab}}$ & $4,291^{\mathrm{ab}}$ & $4,563^{\mathrm{ab}}$ & $1,266^{\mathrm{c}}$ \\
\hline
\end{tabular}

${ }^{\mathrm{a}-\mathrm{d}}$ Means $(\mathrm{n}=4)$ for the same row followed by different letters are significantly $(P \leq 0.05)$ different.

${ }^{1}$ Integrated area counts.

${ }^{2}$ Retention time ( $\left.\mathrm{min}\right)$.

${ }^{3}$ Identification: MS = Mass spectra, ${ }^{(\mathrm{T})}$ Tentatively identifies on the basis of the NBS and NIST libraries, ${ }^{(\mathrm{P})}$ Positively identified by comparison with RT and MS of authentic standards. All components were quantified with total ion chromatogram.

${ }^{4}$ Treatments: 2P1, 3P1, 4P1 and 5P1 = cheeses treated at 200, 300, 400, and $500 \mathrm{MPa}$ respectively, on d 1 of manufacturing; 2P15, 3P15, $4 \mathrm{P} 15$, and $5 \mathrm{P} 15=$ cheeses treated at 200, 300, 400 and $500 \mathrm{MPa}$ respectively, on d 15 of manufacturing.

hyde. Ethanal is produced through lactose metabolism caused by lactic acid bacteria, but it also originates from the breakdown of Thr (Molimard and Spinnler, 1996; Engels et al., 1997). In the present study, ethanal reached the lowest levels in 5P1 cheeses (Table 5). The great decrease in lactic acid bacteria produced at 500 $\mathrm{MPa}$ (Figure 1) in addition to the lower FAA levels found in 5P1 cheeses (Table 1) could explain the lower ethanal content found in these cheeses. Pyruvaldehyde is a dicarbonyl produced by lactic acid bacteria and is involved in the production of cheesy flavor. In this study, concentration of pyruvaldehyde increased with pressure, showing the highest values in 5P1 cheeses. According to Ávila et al. (2006), HP seems to improve the activity of the enzymes involved in citrate metabolism, enhancing the access of the enzymes to their substrates by cell lysis or by increasing the bacteria membrane permeability. Benzaldehyde originates from oxidation reactions of cinnamic acid or phenylacetaldehyde and possesses an aromatic note of bitter almond (Molimard and Spinnler, 1996). Furthermore, pyruvaldehyde could react with phenylalanine producing benzaldehyde (Griffith and Hammond, 1989). 2-Methyl-propanal, 2-methyl-butanal, and 3-methyl-butanal are formed from Val, Ile, and Leu degradation, respectively. 3-Methyl-butanal is associated with a spicy chocolatelike flavor in Parmesan and Proosdij cheeses (Engels et al., 1997), and with malty flavor in Swiss cheeses

Table 8. Abundance ${ }^{1}$ of unresolved peaks in the volatile fraction of ewe milk cheeses

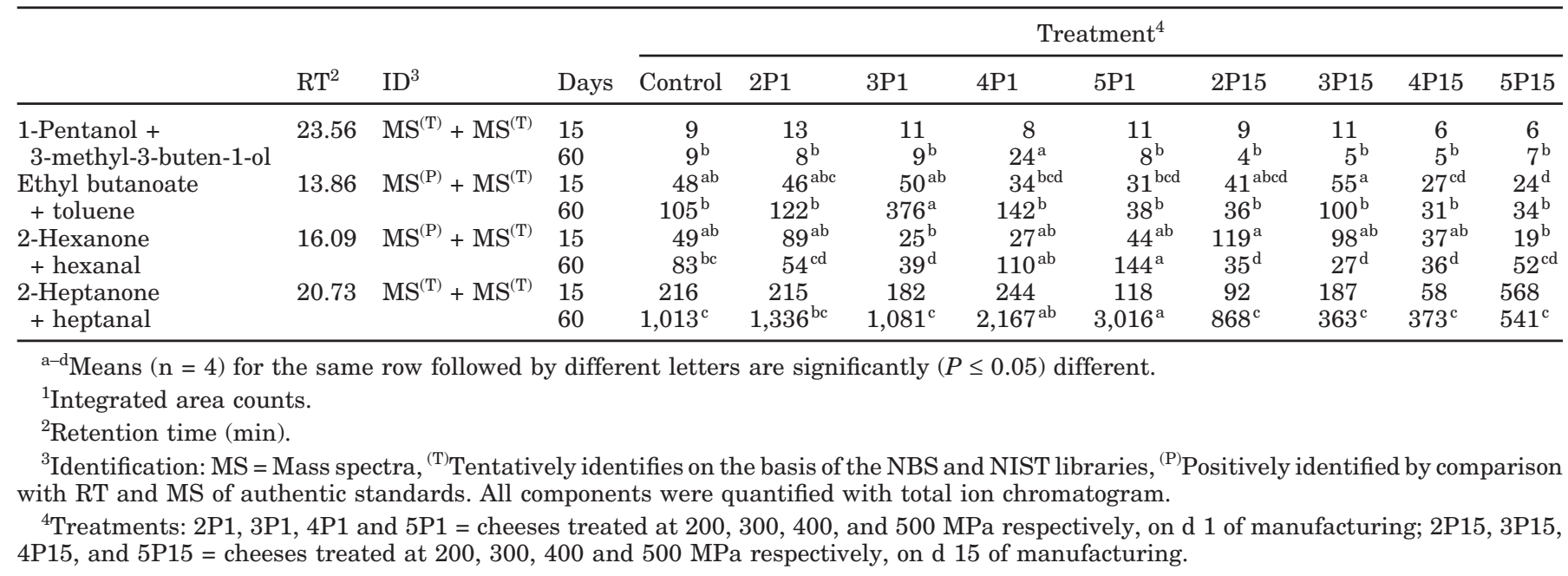




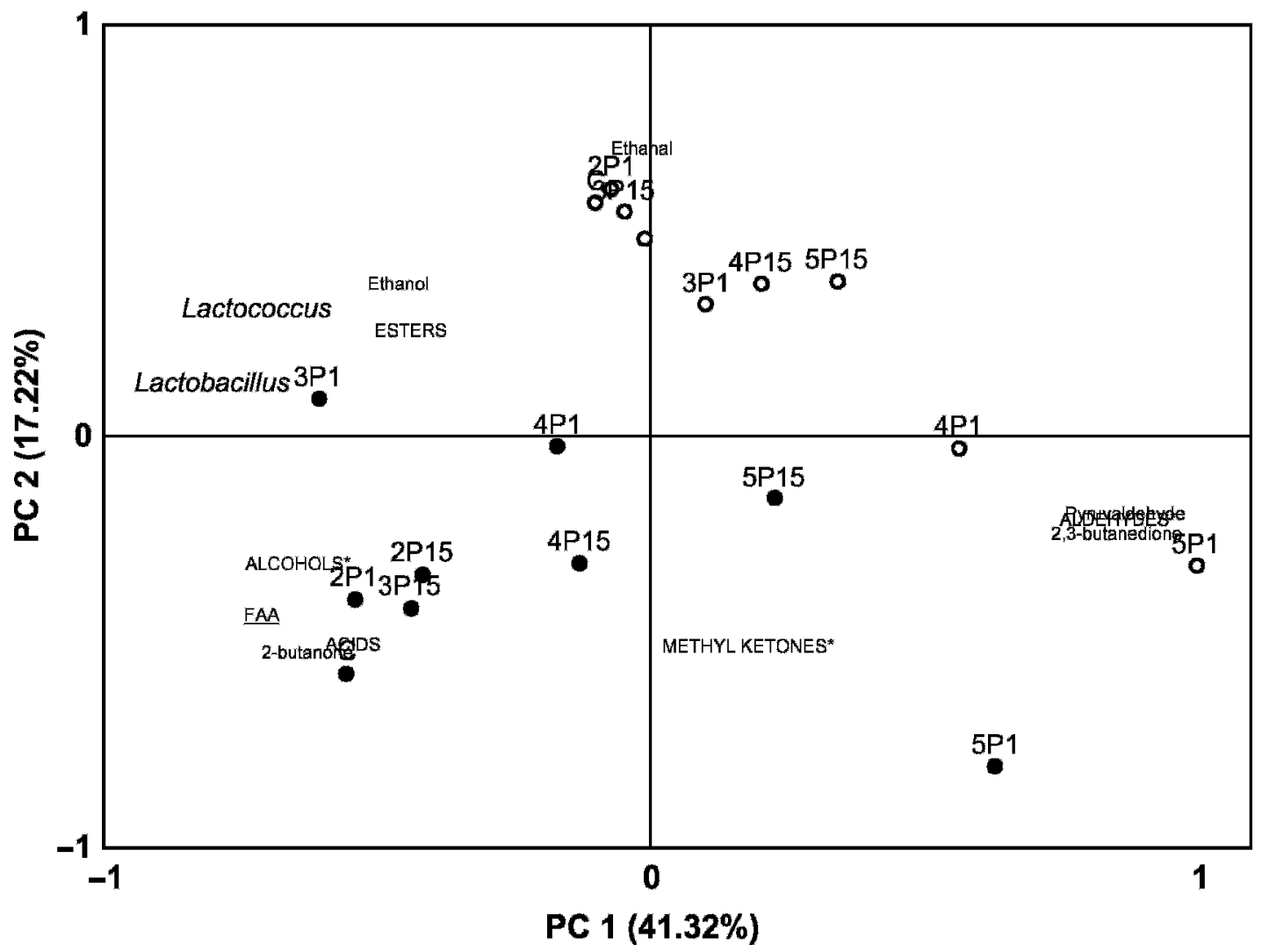

Figure 2. Biplot depicting variable loadings and sample distribution (factor score mean values) from principal component analysis of the volatile composition, free amino acids (FAA), and lactococcus and lactobacillus counts of control and high pressure-treated ewe milk cheeses at $15(\mathrm{O})$ and $60(-)$ d of ripening. Groups of volatile compounds are shown in uppercase font; individual volatile compounds are shown in lowercase font; microorganisms are shown in italic font; ALCOHOLS* = alcohols without ethanol; ALDEHYDES* $=$ aldehydes without ethanal and pyruvaldehyde; METHYL KETONES* = methyl ketones without 2-butanone.

(Griffith and Hammond, 1989). The highest levels of benzaldehyde and branched-chain aldehydes were detected in 3P1 cheeses, which contained the highest amounts of FAA (Table 1). On the other hand, 2-methylbutanal was not detected in $5 \mathrm{P} 1$ cheeses, a fact that could be explained by the lower levels of FAA found in these cheeses (Table 1).

Esters. The biosynthesis of esters during cheese ripening proceeds through esterification and alcoholysis. Esters are important contributors to cheese aroma due to their low perception thresholds (Molimard and Spinnler, 1996) and their high volatility at ambient temperatures. Four ethyl esters were identified in our cheeses (Table 6), although one of them (ethyl butanoate) was classified as an unresolved peak (Table 9) because it was not possible to separate it from toluene. Ethyl acetate has been positively associated with sweet odor in Appenzeller cheese (Lawlor et al., 2001), whereas ethyl butanoate and ethyl hexanoate are correlated with sweet and unripe apple overtones respectively, and play an important role in the aroma profiles of many cheeses (Moio and Addeo, 1998; Curioni and Bosset, 2002; Corrëa Lelles Nogueira et al., 2005). Among the ethyl esters, $4 \mathrm{P}$ and $5 \mathrm{P}$ cheeses did not show detectable levels of ethyl hexanoate, and levels of ethyl octanoate were only detected at $60 \mathrm{~d}$ of ripening in 3P1 cheeses. The abundance of the total ethyl esters was higher in $3 \mathrm{P} 1$ cheeses (Table 6 ), probably because these cheeses contained more ethanol available to esterify (Table 4).

Ketones. Methyl ketones are produced by oxidation of FFA to $\beta$-ketoacids and their consequent decarboxylation to methyl ketones with the loss of one carbon atom (McSweeney and Sousa, 2000). Nevertheless, 2butanone derives from 2,3-butanedione, which is produced by lactose fermentation and metabolism of citrate. Five methyl ketones were identified in cheeses, but 2 of them were components of unresolved peaks (Table 9). 2-Pentanone and 2-hexanone have been associated with fruity and floral flavor, whereas a spicy, musty flavor is associated with 2-heptanone, which is responsible for the characteristic aroma of Roquefort 
and Camembert cheeses (Molimard and Spinnler, 1996). Overall, 4P1 and 5P1 cheeses presented a significant $(P \leq 0.05)$ increase in the abundance of methyl ketones (except for 2-butanone), with 5P1 cheeses showing the highest levels at the end of ripening (Table 7). Pressure treatments at $\geq 400 \mathrm{MPa}$ performed on the first day of ripening could affect the enzyme activity responsible for degrading methyl ketones to alcohols, thus increasing and decreasing levels of methyl ketones and alcohols, respectively, in 4P1 and 5P1 cheeses (Tables 6 and 7).

2,3-Butanedione (diacetyl), with a sweet buttery and vanilla aroma (Molimard and Spinnler, 1996), is obtained from lactose and citrate metabolisms, mainly due to the activity of lactic acid bacteria. 2,3-Butanedione plays an important role in the volatile fraction of a number of fermented dairy products; it is the major aromatic compound in fresh cheese (Engels et al., 1997), and it has been identified as a key aroma component of Camembert, Cheddar, and Emmental cheeses (Curioni and Bosset, 2002). Pressure treatments at $\geq 400 \mathrm{MPa}$ increased the relative abundance of 2,3-butanedione (Table 7). These results could be explained by the improvement of some enzymes involved in the citrate metabolism by the HP treatment, as Ávila et al. (2006) suggested and previously explained. Cheeses in the 5P1 group had the highest level of 2,3-butanedione at 15 and $60 \mathrm{~d}$ of ripening. On the other hand, the HP treatments reduced the amounts of 2-butanone, with the lowest levels being observed in $5 \mathrm{HP}$ cheeses. A decrease in the products from reduction of 2,3-butanedione were found in HP-treated Gouda cheese (Butz et al., 2000) and it was attributed to variations in enzymatic activity due to HP treatment. Ávila et al. (2006) suggested the necessity of the cellular integrity for these enzymatic processes, and the cell lysis produced by HP is probably responsible for the decrease in these compounds.

Lactones and Sulfur Compounds. Lactones are believed to contribute to the buttery sensory character in cheese and seem to be related to lipid degradation, being formed by cyclicization of $\gamma$ - and $\delta$-hydroxyacids. $\delta$-Hexalactone is related to a milk sweet coconut aroma in some cheese varieties (Frank et al., 2004), whereas $\delta$-decalactone is a key odorant of Camembert and Emmental cheeses (Curioni and Bosset, 2002). In the present work, the abundance of total lactones was not affected by the HP treatment (data not shown).

Volatile sulfur compounds play an important role in the flavor of many cheeses as reported by various authors (Molimard and Spinnler, 1996; McSweeney and Sousa, 2000). They are essentially originated from Met degradation (Curioni and Bosset, 2002) and can interact with each other and with other compounds in cheese, generating a diversity of volatile flavor com- pounds. The HP treatment had no clear effect on these compounds, producing a slight decrease in the total sulfur compounds in HP cheeses (data not shown).

Other Compounds. Two hydrocarbons (xylene, nhexane), 2 terpenes (limonene, phellandrene) and ethyl ether were also identified in our cheeses. In the present study, the highest levels of xylene were found in 3P1 cheeses at the end of ripening, whereas hexane and phellandrene levels were not affected by the HP treatment (data not shown). Limonene and ethyl ether were found in HP cheeses at lower levels than in control cheeses (data not shown).

1,4-Dichlorobenzene and methylene chloride were also present in the volatile fraction of cheeses, which could be explained by environmental contamination; these compounds are not important in the cheese flavor.

Table 8 shows 4 unresolved chromatographic peaks, each peak comprising 2 substances. 3-Methyl-3-buten1-ol has been identified in some Italian cheeses and may have originated from plants or from secondary fermentation by nonstarter bacteria. Cheeses in the 3P1 group presented the highest area of the peak formed by ethyl butanoate and toluene as described for other ethyl esters (Table 6). The amounts of 2-hexanone + hexanal and 2-heptanone + heptanal were higher in $5 \mathrm{P} 1$ cheeses, which is related to the higher levels of methyl ketones in 5P1 cheeses (Table 7).

\section{Principal Component Analysis}

Figure 2 represents the loading plots of the variables (volatile compounds) and the factor scores (cheeses) in the 2-dimensional system defined by principal components 1 (PC1) and 2 (PC2), which explained $58.54 \%$ of the total variance. Ethanal, ethanol, 2-butanone, 2,3butanedione, and pyruvaldehyde were treated individually because their behavior differed considerably from their corresponding chemical groups. Aldehydes, 2,3butanedione, and pyruvaldehyde showed high positive loadings ( $>0.84$ ) with PC1, whereas FAA, lactococci, and lactobacilli showed high negative loadings $(>0.71)$ with this factor. 2-Butanone and alcohols were also negatively correlated ( 0.63 and 0.65 , respectively) with PC1. Ethanal showed positive loading (0.63) with PC2, whereas acids and methyl ketones showed negative loadings (>0.57) with this factor. In general, P15 cheeses were more similar to untreated cheeses than $\mathrm{P} 1$ cheeses; in contrast, $2 \mathrm{P} 1$ cheeses were the most similar to the control ones. Pressures $\geq 300 \mathrm{MPa}$ changed the volatile profile of cheeses noticeably. Cheeses in group 5P1 were clearly differentiated by the highest amounts of pyruvaldehyde, methyl ketones (except for 2-butanone), and 2,3-butanedione, and the lowest levels of ethanal, alcohols, 2-butanone, FAA, and 
lactic acid bacteria counts. At $60 \mathrm{~d}$ of ripening, 3P1 cheeses were characterized by higher abundance of ethanol and ethyl esters.

The HP treatment produced changes in the microbiological populations and enzyme activities that modified the volatile profile of cheeses. In general, HP treatment reduced the formation of acids, alcohols, aldehydes, ketones, and sulfur compounds, but enhanced the formation of 2,3-butanedione. The pyruvaldehyde formation was improved by pressures $\geq 400 \mathrm{MPa}$, and the formation of ethyl esters was increased by $300-\mathrm{MPa}$ treatments. These results suggested that HP treatment could produce different effects on bacterial enzymes, depending on the enzyme involved and the pressure level, enhancing or limiting the formation of volatile compounds. On the other hand, according to Juan et al., (2004) pressures $\geq 400 \mathrm{MPa}$ produced a great decrease in the starter counts and FAA levels, indicating that these HP conditions may be useful to arrest cheese ripening at the desired ripening stage.

Future work should be aimed at evaluating the influence of the modifications in the balance of volatile profile produced by HP on the sensory characteristics of ewe milk cheeses.

\section{ACKNOWLEDGMENTS}

The authors acknowledge the Comisión Interministerial de Ciencia y Tecnología for the financial support given to this investigation (CICYT AGL2000-1426C02). B. Juan acknowledges a predoctoral fellowship from the Comissionat per a Universitat i Recerca de la Generalitat de Catalunya, and the Food Techonology Department of Pharmacy Faculty of the University of the Basque Country (Vitoria, Spain) for their kindness during her stay.

\section{REFERENCES}

Ávila, M., S. Garde, E. Fernández-García, M. Medina, and M. Núñez. 2006. Effect of high-pressure treatment and a bacteriocin-producing lactic culture on the odor and aroma of Hispánico cheese: Correlation of volatile compounds and sensory analysis. J. Agric. Food Chem. 54:382-389.

Barron, L. J. R., Y. Redondo, C. E. Flanagan, F. I. Pérez-Elortondo, M. Albisu, A. I. Nájera, M. de Renobales, and E. FernándezGarcía. 2005. Comparison of the volatile composition and sensory characteristics of Spanish PDO cheeses manufactured from ewes' raw milk and animal rennet. Int. Dairy J. 15:371-382.

Butz, P., A. Fernández, W. D. Koller, W. Messens, and B. Tauscher. 2000. Effects of high pressure treatment on fermentation process during ripening of Gouda cheese. High Pressure Res. 19:37-41.

Collins, Y. F., P. L. H. McSweeney, and M. G. Wilkinson. 2003. Lipolysis and free fatty acid catabolism in cheese: A review of current knowledge. Int. Dairy J. 13:841-866.

Corrëa Lelles Nogueira, M. C. L., G. Lubachevsky, and S. A. Rankin. 2005. A study of the volatile composition of Minas cheese. Lebensm. Wiss. Technol. 38:555-563.
Curioni, P. M. G., and J. O. Bosset. 2002. Key odorants in various cheese types as determined by gas chromatography-olfactometry. Int. Dairy J. 12:959-984.

Engels, W. J. M., F. Dekker, C. De Jong, R. Neeter, and S. Visser. 1997. A comparative study of volatile compounds in the watersoluble fraction of various types of ripened cheese. Int. Dairy J. 7:255-263.

Folkertsma, B., and P. F. Fox. 1992. Use of the Cd-ninhydrin reagent to assess proteolysis in cheese during ripening. J. Dairy Res. 59:217-224.

Frank, D. C., C. M. Owen, and J. Patterson 2004. Solid phase microextraction (SPME) combined with gas-chromatography and olfactometry-mass spectrometry for characterization of cheese aroma compounds. Lebensm. Wiss. Technol. 37:39-154.

Griffith, R., and E. G. Hammond. 1989. Generation of Swiss cheese flavor components by reaction of amino acids with carbonyl components. J. Dairy Sci. 72:604-613.

IDF. 1982. Cheese and processed cheese. Determination of the total solids content. Standard 4 A. International Dairy Federation, Brussels, Belgium.

IDF. 1993. Milk determination of the total nitrogen content. Standard 20B. International Dairy Federation, Brussels, Belgium.

Jin, Z. T., and W. J. Harper. 2003. Effect of high pressure (HP) treatment on microflora and ripening development in Swiss cheese slurries. Milchwissenschaft 58:134-137.

Johnston, D. E., and P. C. Darcy. 2000. The effects of high pressure treatment on immature Mozzarella cheese. Milchwissenschaft 55:617-620.

Juan, B., V. Ferragut, B. Guamis, M. Buffa, and A. J. Trujillo. 2004 Proteolysis of high pressure-treated ewe's milk cheese. Milchwissenschaft 59:616-619.

Kolakowski, P., A. Reps, and A. Babuchowski. 1998. Characteristics of pressurised ripened cheeses. Pol. J. Food Nutr. Sci. 7:473-482.

Kuchroo, N. C., and P. F. Fox. 1982. Soluble nitrogen in cheese: Comparison of extraction procedures. Milchwissenschaft 37:331-334

Law, B. A. 1982. Flavour compound in cheese. Perfumer and Flavorist 7:10-21.

Lawlor, J. B., C. M. Delahunty, M. G. Wilkinson, and J. Sheehan. 2001. Relationships between the sensory characteristics, neutral volatile composition and gross composition of ten cheese varieties. Lait 81:487-507.

Lawlor, J. B., C. M. Delahunty, M. G. Wilkinson, and J. Sheehan. 2002. Relationships between the gross, non-volatile and volatile compositions and the sensory attributes of eight hard-type cheeses. Int. Dairy J. 12:493-509.

Marilley, L., and M. G. Casey. 2004. Flavours of cheese products: Metabolic pathways, analytical tools and identification of producing strains. Int. J. Food Microbiol. 90:139-159.

McSweeney, P. L. H., and M. J. Sousa. 2000. Biochemical pathways for the production of flavour compounds in cheeses during ripening: A review. Lait 80:293-324.

Messens, W., I. Foubert, K. Dewettinck, and A. Huyghebaert. 2000. Proteolysis of a high-pressure-treated smear-ripened cheese. Milchwissenschaft 55:328-332.

Moio, L., and F. Addeo. 1998. Grana Padano cheese aroma. J. Dairy Res. 65:317-333.

Molimard, P., and H. E. Spinnler. 1996. Review: Compounds involved in the flavor of surface mold-ripened cheeses: Origins and properties. J. Dairy Sci. 79:169-184.

O'Reilly, C., A. L. Kelly, P. M. Murphy, and T. P. Beresford. 2001. High pressure treatment: Applications in cheese manufacture and ripening. Trends Food Sci. Technol. 12:51-59.

O’Reilly, C., P. M. O'Connor, P. M. Murphy, A. L. Kelly, and T. P. Beresford. 2000. The effect of exposure to pressure of $50 \mathrm{MPa}$ on Cheddar cheese ripening. Innov. Food Sci. Emerg. Technol. 1:109-117.

Ortigosa, M., P. Torre, and J. M. Izco. 2001. Effect of pasteurization of ewe's milk and use of a native starter culture on the volatile components and sensory characteristics of Roncal cheese. J. Dairy Sci. 84:1320-1330. 
Reps, A., P. Kolakowski, and F. Dajnowiec. 1998. The effect of high pressure on microorganisms and enzymes of ripening cheeses. Pages 265-270 in High Pressure Food Science. Bioscience and Chemistry. N. S. Isaacs, ed. Royal Society of Chemistry, Cambridge, UK.

Saldo, J., A. Fernández, E. Sendra, P. Butz, B. Tauscher, and B. Guamis. 2003. High pressure treatment decelerates the lipolysis in a caprine cheese. Food Res. Int. 36:1061-1068.

Saldo, J., P. L. H. McSweeney, E. Sendra, A. L. Kelly, and B. Guamis. 2002. Proteolysis in caprine milk cheese treated by high pressure to accelerate cheese ripening. Int. Dairy J. 12:35-44.
Saldo, J., E. Sendra, and B. Guamis. 2000. High hydrostatic pressure for accelerating ripening of goat's milk cheese: Proteolysis and texture. J. Food Sci. 65:636-640.

Trujillo, A. J., M. Capellas, J. Saldo, R. Gervilla, and B. Guamis. 2002. Applications of high-hydrostatic pressure on milk and dairy products: A review. Innov. Food Sci. Emerg. Technol. 3:295-307.

Urbach, G. 1997. The flavour of milk and dairy products: II. Cheese: Contribution of volatile compounds. Int. J. Dairy Technol. 50:79-89.

Yokohama, H., N. Sawamura, and N. Motobayashi. 1992. Method for accelerating cheese ripening. Eur. Pat. Applic. No. 0469857 A1. 